\title{
PEMIKIRAN TRANSFORMATIF SOEKARNO DALAM POLITIK ISLAM \\ (Pendekatan Transformatif Bill Gould, Karl Stenbrink, dan Kontowijoyo)
}

\author{
Dr. Anwar Sanusi, M.Ag ${ }^{1}$ \\ ucianwarsanusi@yahoo.com
}

\begin{abstract}
ABSTRAK
Soekarno menyeru umat Islam untuk "menggali api Islam", karena Soekarno melihat bahwa kaum Muslimin baik di Indonesia maupun di dunia hanya mewarisi "abu" dan "arang" yang mati dan statis dari warisan kultural. Kemunduran Islam disebabkan karena pensakralan fiqh dan ijma ulama yang kemudian berujung pada penutupan pintu ijtihad, bahkan Fiqh telah menjadi algojo roh semangat Islam. Dalam persoalan tabir, pensucian bekas jilatan anjing, transfusi darah, perbedaan bank dengan riba harus dilakukan rekontruksi kalau Islam ingin maju. Perdebatan mengenai bentuk negara antara nasionalis-sekuler dengan kelompok nasionalis-Islam membuat Soekarno berpikir untuk menemukan formulasi yang bisa diterima oleh semua kelompok, yakni Rumusan Pancasila sila pertama yaitu Ketuhanan Yang Maha Esa yang merupakan akumulasi perdebatan dua kelompok tersebut. Selain perdebatan tersebut, Soekarno juga menghadapi persoalan sistem parlementer yang mengalami jatuh bangun sehingga Soekarno menggagas Demokrasi Terpimpin serta Soekarno menggagas konsep NASAKOM atau integrasi persoalan bangsa dari nasionalisme (PNI), agama (NU), dan sosialisme (PKI) dengan dukungan militer.
\end{abstract}

Kata Kunci: Transformatif, Soekarno, Pancasila, dan Nasakom

\begin{abstract}
Soekarno called on Muslims to "dig up the fire of Islam", because Soekarno saw that Muslims both in Indonesia and in the world only inherited dead and static "ashes" and "charcoal" from cultural heritage. The decline of Islam was caused by the sanctification of fiqh and ijma ulama which then led to the closing of the door of ijtihad, even Fiqh had become the executioner of the spirit of Islamic spirit. In the case of veils, purification of dog licks, blood transfusions, bank differences with usury must be reconstructed if Islam wants to advance. The debate about the form of the state between nationalist-secular and nationalistIslamic groups led Sukarno to think of finding a formulation that could be accepted by all groups, namely the Pancasila Formulation of the first precepts, namely the Almighty Godhead which is the accumulation of the debates of the two groups. In addition to the debate, Soekarno also faced the problem of a parliamentary system which had fallen and so Sukarno initiated Guided Democracy and Sukarno initiated the NASAKOM concept or integration of national problems from nationalism (PNI), religion (NU) and socialism (PKI) with military support.
\end{abstract}

Keywords: Transformative, Sukarno, Pancasila, and Nasakom

\footnotetext{
${ }^{1}$ Mahasiswa Program Doktor Universitas Muhammadiyah Yogyakata (UMY) Program Studi Politik Islam.
} 


\section{A. Biografi dan Perjuangan serta Persentuhan Soekarno dengan Pemikiran Islam}

1. Biografi Singkat Soekarno

Soekarno dilahirkan pada tanggal 6 Juni 1901 M dan bertepatan pada tanggal 18 Safar 1831 H., beliau dilahirkan pada hari Kamis Pon dalam penanggalan Jawa. Ia dilahirkan di desa Lawang Sekaten Surabaya. ${ }^{2}$ Soekarno dilahirkan saat fajar mulai menyingsing sehingga ayahnya menganggap bahwa anaknya sebagai "sang fajar" yang dilahirkan dalam abad Revolusi Kemanusiaan. Soekarno meninggal dunia pada hari Minggu tanggal 21 Juni 1970 di Rumah Sakit Angkatan Darat (RSPAD) Jakarta. Beliau dishalatkan di Wisma Yaso Jakarta dan dimakamkan di daerah kelahirannya, Blitar Jawa Timur di dekat makam ibundanya, Ida Ayu Nyoman Rai. Pemerintah RI meng-anugerahkan Soekarno sebagai Pahlawan Proklamasi. ${ }^{3}$ Nama asli Soekarno pada masa kelahiran bernama

\footnotetext{
${ }^{2}$ Benhard Dahm, Soekarno dan Perjuangan Kemerdekaan, Terj. Hasan Basri, (Jakarta : LP3ES : 1987). hlm. 322. Tetapi Ada pendapat lain yang menyebutkan bahwa Lawang Sekaten berada di wilayah Blitar dan bukan Surabaya/ untuk leih jelas lihat http://ngoceh.us/menu/read/618

Badri Yatim, Soekarno Islam dan Nasionalisme, (Jakarta : Inti Aksara : 1985), hlm. 5. Lihat Juga T. B., Simatupang, Antara Citra dan Fakta, dalam Aristides Katoppo (ed.), 80 Tahun Bung Karno, (Jakarta : Sinar Harapan ; 1982), hlm. 27. Ada pendapat lain yang menyebutkan bahwa Lawang Sekaten berada di wilayah Blitar dan bukan Surabaya/
}

Kusno Sosrodihardjo. ${ }^{4}$ Pada usia lima tahun diubah menjadi Soekarno, ${ }^{5}$ yang diambil dari nama Karna dan berubah menjadi Karno. ${ }^{6}$ Di beberapa negara Barat, nama Soekarno ditulis dengan penambahan nama Achmed menjadi Ahmed Soekarno. ${ }^{7}$

2. Pendidikan Formal Soekarno Pada tahun 1907 Soekarno masuk Sekolah Dasar atau Sekolah Rakyat (SR) di Tulung Agung. ${ }^{8}$ Pada tahun 1908, Soekarno masuk Sekolah Dasar di HIS Mojokerto sampai lulus tahun 1913 dan melanjutkan ke Europesche Legore School (ELS) di Mojokerto dan selesai tahun $1916 .{ }^{9}$ Selain pendidikan formal, Soekarno ikut les bahasa Prancis dan ia sangat fasih. ${ }^{10}$ Pada tahun 1914, Soekarno ingin melanjutkan ke sekolah dasar berbahasa Belanda. ${ }^{11}$ Namun ditolak masuk ke kelas enam, karena kurang mampu bahasa Belanda. Ia diterima di kelas

4 Peter Kasenda, Soekarno Muda: Biografi Pemikiran 1926-1933, (Jakarta. : Komunitas Bambu : 2010) hlm. 11.

${ }^{5}$ Cindy Adams, Bung Karno Penyambung Lidah Rakyat Indonesia. (Jakarta : Gunung Agung :1984), hlm. 35-36.

${ }^{6}$ Soekarno, Dibawah Bendera Revolusi, jilid pertama cet. ke dua (Jakarta : Panitia Dibawah Bendera Revolusi : 1963), hlm., 410.

${ }^{7}$ Cindy Adams, Bung Karno Penyambung Lidah Rakyat Indonesia. Op. cit, hlm. 37.

${ }^{8}$ Tamar Djaya, Soekrno Hatta Ada Persamaan dan Perbedaannya, (Jakarta : Sastra Hudaya : 1983), hlm. 28. Baca juga J. D. Legge, Soekarno, Sebuah Geografi Politik, Terj. Tim PSH, (Jakarta ; Sinar harapan : 1985), hlm. 21.

${ }^{9}$ Ibid., hlm. 30.

10 Solihin Salam, Soekarno Sebagai Manusia, (Solo ; Boeckhandel Ravena ; 1933), hlm., 24. 
lima. ${ }^{12}$ Soekarno menerima perlakuan diskriminasi para guru Belanda. Kondisi ini menumbuhkan semangat patriotisme akan nasib yang dialami bangsa Indonesia. $^{13}$ Setelah lulus ELS, Soekarno melanjutkan ke Hogere Burger School (HBS) di Surabaya tahun 1916, ${ }^{14} 10$ Juni 1921 ia lulus dan berniat meneruskan pendidikannya ke Belanda, namun tidak diizinkan oleh ibunya. ${ }^{15}$ Pada bulan Juni 1921 Soekarno menjadi mahasiswa di Sekolah Tinggi Teknik atau Tachnishe hoge School (THS) Bandung dan pada tanggal 25 Mei 1928 dan ia memperoleh gelar Insinyur Teknik. ${ }^{16}$

Soekarno mendapat gelar Doktor Honoris Causa dari : Universitas Gajah Mada, Universitas Indonesia, Institut Teknologi Bandung, Universitas Padjadjaran, Universitas Hasanuddin, Institut Agama Islam Negeri Jakarta, Columbia University (Amerika Serikat), Berlin University (Jerman),

${ }^{11}$ Ibid., hlm. 22.

${ }^{12}$ Cindi Adam, Bung Karno Penyambung Lidah Rakyat Indonesia, Loc. cit hlm., 32.

13 J. D. Legge, Soekarno, Sebuah Geografi Politik, Loc. cit , hlm. 21

${ }^{14}$ Bernard Dahm, Bernard Dahm, Soekarno dan Perjuangan Kemerdekaan, Loc. cit., hlm., 27.

15 J. D. Legge, Soekarno, Sebuah Geografi Politik, Loc. cit , hlm. 21

${ }_{16}$ Sagimun, Perlawanan dan Pengasingan Pejuang Nasioal, (Jakarta: Idayu : 1986), hlm. 149. untuk lebih jelas lihat Ingleson, John, Jalan Ke Pengasingan, Pergerakan Nasional Indonesia tahun 1927-1934, Terj. Zamakhsari Dhofier, (Jakarta ; LP3ES. : 1983), hlm. 150.
Lomonosov University (Moscow), Al-Azhar University (Cairo). ${ }^{17}$

\section{Pendidikan Non Formal}

Penulis menganalisa

Pendidikan non formal Soekarno, yaitu: pertama, mondok di rumah H.O.S. Tjokroaminoto ${ }^{18}$ yang banyak dikunjungi tokoh-tokoh seperti: Muso, Alimin, Dharsono, Tan Malala, Sekarmadji Marijan Kartosoewirjo, Hadji Agus Salim, Abdoel Moeis, K.H. Ahmad Dahlan, ${ }^{19}$ dan Ki Hadjar Dewantara. $^{20}$ Tjokroaminoto mengajarkan agama dan cara membaca al-Qur'an ${ }^{21}$ serta

${ }^{17}$ Imam Toto K. Rahardjo dan Suko Sudarso (ed) Soekarno ; Islam Pancasila NKRI (Jakarta : Komunitas Nasionalis Religius Indonesia : 2006), hlm., 32

${ }^{18}$ Soekarno di Surabaya tinggal di rumah tokoh Islam dan pergerakan serta petinggi organisasi massa Sarekat Islam yang radikal dan memiliki anggota paling banyak.

${ }^{19}$ Arif Zulkifli dkk. (Ed.). Sukarno: Paradoks Revolusi Indonesia. (Jakarta : KPG ; 20100, hlm. 18.

${ }^{20}$ Ibid., hlm. 42-43)

${ }^{21}$ Rumah tembok dengan atsitektur Jogjakarta bercat warna putih dan hijau tua iru merupakan tempat bersejarah bagi bangsa Indonesia. Rumah itu banyak "melahirkan" tokoh pencetus proklamasi kemerdekaan Republik Indonesia. Rumah tua yang masih terawat apik itu mudah ditemukan, letaknya di J1 Peneleh VII Nomor 2931 dekat dengan toko buku Peneleh (salah satu toko buku tua yang ada di Surabaya, tunggu di artikel selanjutnya) di Kecamatan Genteng Surabaya, diperkirakan dibangun pertengahan tahun 1800. "Meskipun letaknya di tengah-tengah kota, tapi belum banyak diketahui masyarakat," ujar Imma Nadima Simbolon yang sehari-hari menjaga rumah itu. Menurut Imma, perempuan berusia sekitar 70-an, Cokroaminoto yang mempunyai panggilan "raja tanpa mahkota", sebenarnya dilahirkan di kota gudeg Jogjakarta pada 16 Agustus 1883. Sekitar tahun 1900, ia hijrah ke kota Surabaya untuk berjuang bersamasama sahabatnya guna melepaskan Indonesia dari cengkeraman penjajah Belahda. Di Surabaya ia 
mengajarkan tentang apa dan siapa ia. ${ }^{22}$ Kedua, tinggal di Rumah $\mathrm{H}$. Sanusi Bandung. Haji Sanusi, seorang anggota Sarekat Islam dan sahabat karib Tjokroaminoto. Soekarno mematangkan intelektualitas dan intelegensi. Ia berkenalan dengan $\mathrm{Ki}$ Hajar Dewantara, Tjipto Mangunkusumo dan Dr. Douwes Dekker tentang gagasan Nasionalisme Sekuler dan Realisme-Sosial Komunis. ${ }^{23}$ Ketiga, Penjara Sukamiskin. Soekarno berkenalan dengan A. Hasan dari Persatuan Islam (PERSIS). Ia sering berdebat mengenai Islam dan Nasionalisme ${ }^{24}$ belajar mengkaji al-Quran dan banyak membaca buku Lathrop Stoddard dan Syed Ameer Ali. ${ }^{25}$ Keempat, Penjara Ende. Soekarno menjalin hubungan dengan A. Hasan yang banyak mengirimi buku-buku keagamaan seperti Pengajaran Shalat, Utusan Wahabi, Al-ukhtar, Debat Talqin, Al-Burhan, Al-Jawahir, dan SoalJawab agama. ${ }^{26}$

menempati rumah di Peneleh Gang VII yang terletak di tepi Kali Mas. Tahun 1931 ia kembali ke Jogja dan wafat di sana 17 Desember 1934 dan dimakamkan di Jogja.

${ }^{22}$ Cindy Adams, Bung Karno Penyambung Lidah Rakyat Indonesia. Terj. Abdul Bar Salim, Loc. cit., hlm. 53.

${ }^{23}$ Ibid., hlm. 5.

24 Solichin Salam, Bung Karno dan Kehidupan Berpikir dalam Islam. (Jakarta: Wijaya, 1964), hlm. 30. 31

${ }^{25}$ Lihat juga analisis Legge, Op, cit., hlm. 30-

${ }^{26}$ Benhard Dahm, Soekarno dan Perjuangan Kemerdekaan, Terj. Hasan Basri, Loc. cit., hlm. 74-75. Baca juga Onghokham "Soekarno: Mitos dan Realitas" dalam Taufik Abdullah, Aswab
Kajian ini berbeda dengan kajian politik Islam pada umumnya, yang lebih mengedapak substansi pemikiran dari pada konteks diartikulasikannya pemikiran itu. ${ }^{27}$ Bahwa pemikiran, terkait dengan obsesi orang yang bersangkutan. ${ }^{28}$ Se-hubungan dengan hal itu, telaah ini dilakukan dengan asumsi bahwa apa yang dipikirkan Sukarno didasari nilai-nilai yang mengobesi dirinya. Mengingat posisinya dominan yang didudukinya sebagai negarawan, maka pemikiran yang ditelaah di sini diasumsikan menjadi bagian dari kenegarawanannya. Sinyalemen ini tidak harus menafikan bahwa dalam hidupnya terlihat pergeseran orientasi ke arah yang semakin agamis.

Sebagaimana tertera dalam judul naskah ini, muara dari telaah ini adalah pemikiran transformatif. Bahwa, melalui telaah terhadap pemikiran yang dikaitkana dengan konteks kehidupan dan perjuangannya, pemikiran Sukarno bersifat transformatif. Watak trans-

Mahasin, dan Daniel Dhakidae. 1983. Manusia dalam Kemelut Sejarah. (Jakarta : LP3ES : 1983), hlm. 20.

${ }^{27}$ Faktor inilah yang menyebabkan Soekarno melahirkan pemikiran, gagasan, dan aktivitas. Begitu juga dengan pandangan Mulyanto Sumardi bahwa pemikiran tokoh tak akan lahir tanpa adanya konteks yang melingkunginya. Untuk lebih jelas baca Mulyanto Sumardi, Penelitian Agama Masalah Dan Pemikiran (Jakarta: Sinar Harapan, 1982 ), hlm. 64.

${ }^{28}$ Karel A. Steenbrink, Metodologi Penelitian Agama Islam di Indonesia Beberapa Pentunjuk Mengenai Penelitian Naskah melalui: Sya'ir Agama Dalam Bahasa Melayu Dari Abad 19 (Semarang: LP3M IAIN Walisongo, 1988 ), hlm. 4. 
formatif itulah yang pada akhirnya mengantarkan serangkaian gagasan yang tidak populer pada zamannya namun relevan untuk dikemukan.

\section{B. Pendekatan dan Teori}

Kajian ini berbeda dengan kajian politik Islam pada umumnya, yang lebih mengedepankan substansi pemikiran dari pada konteks yang diartikulasikan pemikiran itu. ${ }^{29}$ Bahwa pemikiran, terkait dengan obsesi orang yang bersangkutan. ${ }^{30}$ Sehubungan dengan hal itu, telaah ini dilakukan dengan asumsi bahwa apa yang dipikirkan seseorang didasari nilai-nilai yang mengobesi dirinya.

Terkait dengan pernyataan di atas, gerak interlektual soekarno dan gerak sosial politik Soekarno terobsesi kepercayaan atau ideologi, pemikiran dan perilakunya, yang dijiwai oleh nilai-nilai liberal, humanis, dan transcendental.

Dalam sub bab ini, akan dijelaskan kerangka pikir yang pada akhirnya mengantarkan penulis pada kesimpulan bahwa Soekarno memiliki pemikiran politik Islam yang transformatif. Dalam kajian ini, issue sekularisme hanyalah salah satu dari berbagai (keseluruhan) issue yang dipikirkannya. Telaah di-maksudkan untuk memahami pem-baharuan

${ }^{29}$ Mulyanto Sumardi, Penelitian Agama Masalah Dan Pemikiran (Jakarta: Sinar Harapan, 1982 ), hlm. 64.

${ }^{30}$ Karel A. Steenbrink, Metodologi Penelitian Agama Islam di Indonesia Beberapa Pentunjuk Mengenai Penelitian Naskah melalui:Sya'ir Agama Dalam Bahasa Melayu Dari Abad 19 (Semarang : LP3M IAIN Walisongo, 1988 ), hlm. 4. keislaman dan sekularisme sebagai bagian dari keseluruhan pe-mikiran Islam politik.

Penulis menggunakan ide-ide dasar dari transformasi Bill Gould seorang Pakar Transformational Thingking, yang dijelaskan oleh Daldiyono dalam bukunya berjudul, How to Be a Real and Successful Student. Bahwa dalam proses transformasi, senantiasa ada tiga sistem yang beroperasi secara simultan, yakni sistem perilaku (behavior system), sistem ber-pikir (thingking system) dan sistem kepercayaan (bilief system). ${ }^{31}$ Karena ini adalah studi tentang pemikiran, maka kehirauan langsung penulis adalah sistem thinking. Hanya saja, berangkat dari teorisasi Gould, system thinking yang beroperasi ini tidak bisa dilepaskan dari dua sistem yang lain, yakni sistem perilaku dan sistem kepercayaan. Ketika pemikiran Soekarno ditelaah di bab-bab berikut dalam naskah ini, sistem tersebut selalu dipahami kaitannya satu sama lain.

Praktik berpikir, sebagaimana diajarkan oleh Gould di atas, niscaya berlangsung dalam sautu rangkaian sistemik. Artinya betapapun mengejutkan hal yang dipikirkan dan kemanapun arah pemikirannya tetap saya bisa melacaknya karena adanya keterkaitan sistemik. Ada rasionalitas yang khas yang menandai tapaktapak pemikiran seseorang, termasuk pemikiran Soekarno. 
Sistem pemikiran yang dibahas di sini adalah yang bisa dipinjam untuk mengungkap pemikiran Soekarno. Dari berbagai corak sistem pemikiran yang teridentifikasi, penulis terbantu oleh kerangka analisis yang dipakai oleh Kuntowijoyo. Jelasnya selain Bill Gould sebagai acuan pangkal, penulis juga menggunakan menggunakan kerangka analisis Kuntowijoyo, tentang pemikiran transformatif. Telaah Kuntowijoyo ini sangat membantu memahami arah pemikiran seseorang, terutama yang terkait dengan pemikiran keagamaan. Lebih jelasnya, yang diacu adalah epistemologi yang diadopsi beliau yakni epistimologi integralistik. ${ }^{32}$ Perlu di-tegaskan di sini, bahwa yang dirujuk di sini adalah kerangka analisis yang dipakai Kuntowijoyo dalam meng-analisis pemikiran seseorang, bukan isi pikirannya tentang Islam.

Kerangka pikir ini ditemukan dari pembacaan secara seksama buku-buku Kuntowijoyo yang berjudul Identitas Pilitik Umat Islam. Di sana terdapat beragam istilah di antaranya Trans-formasi Politik dan Transformasi Budaya. Bagi Kuntowijoyo, manifestasi pemikiran transformatif harus ditemukan dari pemilahan antara Transformatif yang Politis dengan Transformatif yang

\footnotetext{
${ }^{31}$ Daldiyono, How to Be a Real and Successful Student. (Jakarta : PT Gramedia Pustaka Utama. ; 2009), hlm. 144.

${ }^{32}$ Untuk lebih jelas, lihat Kuntowijoyo, Islam Sebagai Ilmu ; Efistimologi, Methodologi dan Etika, (Yogyakarta : Tiara Wacana ; 2006), hlm. 27-47.
}

bersifat kultur. Proses transformasi merujuk pada perubahan nilai atau orientasi.

Ada tiga nilai yang diusulkan oleh Kuntowijoyo untuk menandai arah transformasi yang dia usulkan, yakni: (1) libetry, (2) humanity, dan (3) transendensi. Proses tranformasi yang diidealkan beliau adalah mengarah pada liberalisasi, humanisasi, dan transendental.

Berangkat dari tatawan Kuntowijoyo tersebut di atas, studi ini memaknai liberty, sebagai pembebas keterpurukan. Dengan konsep ini, maka setiap gerakan baik itu gerakan pemikiran intelektual maupun gerakan sosial politik yang bertujuan untuk membebaskan belenggu keterpurukan, ketertinggalan, keterjajahan dan keterbelakangan akan dimaknai sebagai pembebasan (liberasi).

Istilah humanity dipakai dalam pengertian konsep Kuntowijoyo adalah menghormati dan menghargai manusia, yakni menolak ketidakadilan, diskriminatif, dan rasis. Dengan konsep ini, maka setiap gerakan baik itu gerakan pemikiran intelektual maupun gerakan sosial politik yang bertujuan untuk menolak kolonialis, diskriminasi, dan rasisme akan dimaknai sebagai hu-manisasi.

Adapun tentang transendensi, penulis bermaksud untuk menekankan bahwa segala sesuatu yang ada di bumi adalah kehendak dan untuk Tuhan. Dengan konsep ini, maka setiap gerakan baik itu gerakan 
pemikiran intelektual maupun gerakan sosial politik yang bertujuan hanya semata-mata pengabdiannya kepada Dzat yang Maha Transenden.

Kelangsungan transformasi itu niscaya melibatkan berbagai kekuatan penggerak. Karena penekanan Kuntowijoyo dalam penyusunan kerangka pikir ada pada aspek epistemologis, kerangka pikir itu tidak cukup detail dalam menjelaskan apa yang menggerakkan pemikiran. Oleh Kuntowijoyo memang ditunjukkan adanya kekuatan politik dan kekuatan kultural namun tidak tersedia petunjuk detail untuk memahami energi penggerak suatu pemikiran. Sehubungan dengan hal itu, studi ini meminjam kerangka analisis Karl Stembrink dalam memahami gerak transformatif. Karl Steenbrink membagi dua alur gerak transformatif, yakni gerak transformatif intelektual dan gerak transformatif sosial politik. Pemilahan ini sangat tepat ketika digunakan untuk menelaah pemikiran Soekarno, yang bukan hanya sibuk berpikir melainkan juga gigih mentransformasikan realita sosial pada jamannya. Soekarno bukan hanya pemikir yang sangat artikulatif dalam menyampaikan gagasan-gagasannya, melainkan juga sangat mengakar pada masyarakat pada jamannya.

Tipologi yang ditawarkan Stembrink sangat membantu dalam memperlakukan Soekarno sebagai pemimpin pergerakan. Artinya, yang penting untuk dipegang dalam menggunakan kerangka pikir Karl Steenbrink bukan hanya adanya dua kategori tersebut, melainkan adanya saling keterkaitan antara keduany. Asumsinya, Soekarno sukses memipin Indonesia karena sanggup mempertemukan dua dimensi gerakan: gerak intelektual dengan gerak sosial. Poin ini perlu dikedepankan karena kenyataan bahwa Soekarno adalah pemimpin pergerakan yang memiliki tapak yang jelas di kedua sisi tersebut. Dalam aktualisasi kepemimpinannya, Soekarno niscaya menghayati gerak sosial masyarakat Indonesia untuk diartikulasikan dalam pemikirannya, dan juga sebaliknya, memimpin pergerakan untuk mewujudkan gerak intelektual yang menggelora dalam dirinya.

Dengan mengkaitkan dua kategori Karl Steenbrink tersebut di atas, juga terbuka peluang untuk mengantisipasi perubahan gerak pemikirannya. Atinya, dalam kapasitas dan posisinya sebagai pemimpin, ada kalanya tekanan Soekarno lebih mengedepankan gerak sosialnya dan dalam situasi ini gerak pemikiran yang ada dalam dirinya menjadi penopang gerak sosial tersebut. Namun, dalam kesempatan lain, Soekarno mendedikasikan dirinya melalui pergumulannya dengan gerak sosial, dan pada gilirannya, dari per-gumulan dalam gerak sosial itu mengkristal dalam gerak intelektualnya. Dengan kerangka pikir ini, bisa di-antisipasi perbedaan pemikiran Soekarno ketika 
masih muda dengan pemikiran Soekarno setelah dewasa.

Perlu juga ditegaskan bahwa dalam telaah ini, Soekarno diasumsikan tidak terisolasi dari sistem-sistem bergulir. Oleh karena itu, keterkaitan antara pe-mikiran atau gerak intelektual (dalam istilah Karl Steenbrink) bisa dibayangkan sebagai resultante dari bekerjanya tiga sistem yang dijelaskan Gould. Jelasnya, kalaulah secara personal Soekarno adalah pemikir yang independent, independency itu, bagaimanapun juga diwarnai oleh dinamika sistem sebagai dipahami oleh Gould. Tiga lapir sistem yang dipetakan oleh Gould diposisikan sebagai back-ground penting dalam pelacakan pemikiran Soekarno. Dalam konteks ini segera terpetakan, bahwa gerak sosial (sebagaimana disebut Stembrink) terkait dengan sistem. Sejalan dengan hal itu, gerak intelektual (dalam istilah Stembrink) bekerja sebagai suatu sistem berpikir (dalam istilah Gould). Implikasinya ketika kita memberlakukan epistemologi integratif yang ditawarkan Kuntowijoyo, kita bisa membayangkan proses berpikir yang dilakukan seseorang (dalam hal ini Soekarno) adalah proses yang terpola sebagai suatu sistem, di mana di dalamnya ada seorang pemimpin (Soekarno) yang mengarungi sistem itu untuk meciptakan perubahan.

Gould menerjemahkan nilai "transformatif" dalam sistem perilaku, sistem berpikir dan sistem kepercayaan relevan dengan transformatif versi Kuntowijoyo yang memaknai transformatif dengan liberalisasi, humanisasi, dan trasendental, maka penulis rumuskan sebagai berikut.

1. Sistem kepercayaan Bill Gould jika dihubungkan dengan teori transformatif Kuntowijoyo yang memaknai transformatif sebagai "liberal-isasi (pembebasan keterpurukan), humanisasi (memanusiakan manusia), dan transendental (transformasi Ilahiyah)", maka "sistem kepercayaan", yang transformatif adalah sistem kepercayaan yang memiliki roh liberalisasi, humanisasi, dan transendental. Kalau sistem kepercayaan dimaknai sebagai ideologi, maka ideologi tersebut adalah ideologi untuk membebaskan keterpurukan manusia seperti kebodohan, ke-miskinan, ketertinggalan. Sistem ke-percayaan yang humanis berpihak pada nilai kemanusiaan, dan ideologi yang transendental yang dilandasi nilai-nilai ilahiyah.

2. Sistem perilaku transformatif Bill Gould jika jika dihubungkan dengan teori transformatif Kuntowijoyo yang memaknai transformatif sebagai "li-beralisasi (pembebasan keterpurukan), humanisasi (memanusiakan manusia), dan transesndental (transformasi Ilahiyah)", adalah sistem perilaku yang dijiwai karakter liberalisasi, humanis, dan tran- 
sendental. Perilaku yang didasari pemikiran rasional dan empiris cenderung memberikan pembebasan dari keterpurukan. Sedangkan perilaku humanis Kuntowijoyo cenderung pada pemahamahan untuk memanusiakan manusia. Perilaku transendental mengarah pada perilaku yang berorientasi teologis, mendasarkan keseluruhannya pada nilai-nilai transendental.

3. Sistem berpikir transformatif Bill Gould jika jika dihubungkan dengan teori transformatif Kuntowijoyo yang memaknai transformatif sebagai "liberalisasi (pembebasan keterpurukan), humanisasi (memanusiakan manusia), dan transesndental (transformasi Ilahiyah)", maka mengandung pembebasan yang seluasluasnya untuk melakukan transformasi. Kebebasan berpikir ini masuk pada wilayah profane dalam kontek politik dan negara. Tetapi faham ini bukan berarti melepaskan agama, karena agama memiliki wilayah tersendiri yang sakral. Sedangkan sistem berpikir humanis didasari pada pemikiran yang rasional berpijak pada pengalaman empiris. Pemikiran humanis cenderung mengangkat derajat manusia manusia. Pemikiran transendental mengarah pada pemikiran yang berorientasi teologis, mendasarkan keseluruhannya pada nilai-nilai transendental yang berlaku di ma- syarakat dengan mengangkat persamaan dan bukan mempermasalahkan perbedaan di antara keyakinan, budaya, ras, warna kulit, dan lain-lain.

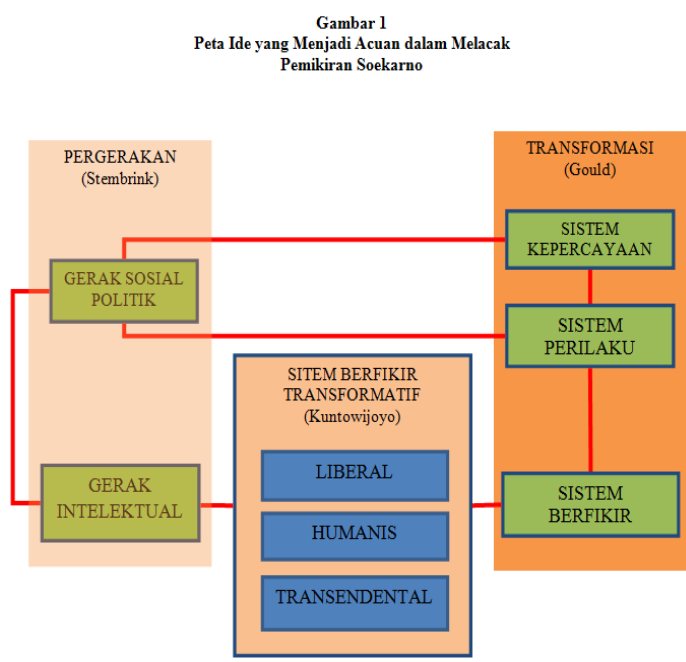

Penulis memadukan ide-ide dasar transformatif Bill Gould dalam sistem perilaku, sistem berfikir dan sistem kepercayaan dengan transformatif versi Kuntowijoyo yang memaknai trans-formatif dengan liberalisasi, humanisasi, dan trasendental. Selanjutnya, penulis jabarkan konsep di atas dalam dua gerak transfromatif yang sesuai dengan pendapat Karl Steenbrink, yakni dalam dua alur gerak transformatif sosial politik dan gerak transformatif intelektual. Menurut penulis, Ide-ide dasar transformatif Bill Gould relevan dengan transformatif Kuntowijoyo dan Karl Stembrink dengan rumusannya sebagai berikut.

1. Sistem kepercayaan dan Sistem perilaku dari teori transformasi Bill Gould bertemu dengan gerak sosial politik Karl Steenbrink.

2. Sistem berpikir dari teori transformasi Gould bertemu dengan 
konsep transformatif yang memaknai transformatif dengan liberalisasi, humanisasi, dan transendental Kuntowijoyo menjadi gerak intelektual Karl Stembrink.

Teori-teori transfromatif di atas, Bill Gould, Kuntowijoyo, dan Karl Stembring relevan dengan Pemikiran Transformatif Soekarno dalam politik Islam, yakni sebagai berikut.

1. Sistem kepercayaan dan Sistem perilaku dari teori transformasi Bill Gould bertemu dengan gerak sosial politik Karl Steenbrink dalam pemikiran Soekarno melahirkan pemikiran pembaharuan dalam Islam dan pemikiran sekular.

2. Sistem berpikir dari teori transformasi Gould bertemu dengan konsep transformatif Kuntowijoyo yang memaknai transformatif dengan liberalisasi, humanisasi, dan transendental menjadi gerak intelektual Soekarno.

Dari analisa di atas, maka menurut penulis bahwa ide-ide dasar transformatif yakni Sistem kepercayaan dan Sistem perilaku serta Sistem berpikir dari teori transformasi Bill Gould, transformatif versi Kuntowijoyo yang memaknai transformatif dengan liberalisasi, humanisasi, dan transendental serta gerak intelektual dan sosial politik Karl Stembrink sangat untuk mengkaji pemikiran transformatif Soekarno dalam politik Islam.

Berangkat dari ide-ide dasar transformatif, yakni sistem kepercayaan dan sistem perilaku serta sistem berfikir dari teori transformasi Bill Gould, transformatif versi Kuntowijoyo yang memaknai transformatif dengan liberal-isasi, humanisasi, dan trasendental serta gerak intelektual dan sosial politik Karl Stembrink, penulis melihat dari sisi pemikiran Soekarno yang mengalami transformatif dalam dua hal, yakni: pemikiran transformatif sebelum kemerdekaan, yakni tentang ide-ide pembaharuan Soekarno dalam Islam dan pemikiran transformatif setelah kemerdekaan, yakni pemikiran tentang Sekularisasi politik Islam Soekarno.

\section{C.Pemikiran Pembaharuan dan Perilaku Politik Soekarno}

1. Ide-ide pembaharuan Soekarno dalam Pemikiran Islam sebelum kemerdekaan

Kajian tentang Pemikiran Transformatif Ir. Soekarno dalam Politik Islam sangat menarik, karena paling tidak akan memunculkan beragam pemikiran dalam Islam. Pembahasan pemikiran sekularisasi politik Islam akan melahirkan pemikiran tradisional yang berhadapan dengan kelompok modernis integralistik, 
kelompok tekstualis berhadapan dengan kelompok kontekstual. ${ }^{33}$

Luthfi Assyaukani mengklasifikasikan kelompok dalam Islam, yaitu: Pertama, kelompok Islam Tradisionalis yaitu kelompok Islam Adat atau Customary Islam. Kedua, kelompok Islam Modernis yaitu kelompok Islam mutahawwil atau kelompok liberal-modernis atau kelompok Islam reformistik. Ketiga, kelompok Islam Liberalis yaitu kelompok Islam mutahawwil yang berpandangan bahwa tidak ada otoritas teks, yang ada hanya otoritas akal, kelompok LiberalSekularis atau kelompok Islam Transformatik. Keempat, kelompok Islam Fundamentalis yaitu kelompok Islam al-Tabit, kelompok Islam Revivalis atau kelompok Islam Ideal-Totalistik.

Sementara untuk perkembangan pemikiran umat Islam Indonesia mengalami beberapa kecenderungan, yaitu: Pertama, Gerakan liberalisasi yang diusung Harun Nasution yang dikenal "Islam Rasional"-nya dan Nurcholishh Madjid dengan "Sekularisasi" sebagai penggerak "pemikiran baru", ${ }^{34}$ serta gerakan

33 Haedar Nashir, Gerakan Islam Syariat : Reproduksi Salafiah Idiologis di Indonesia, (Jakarta: Pusat Studi Agama dan Peradaban (PSAP) Muhammadiyah : 2007)., hlm. 108.

34 Nurcholishh Madjid menyatakan bahwa Umat Islam Indonesia telah mengalami kejumudan dalam pemikiran dan pengembangan ajaran-ajaran Islam. Kemudian Ia menganjurkan untuk melakukan "Liberalisasi pandangan terhadap ajaran-ajaran Islam" melalui proses sekularisasi, arus pemikiran kontemporer yang berkembang di Islam dan Barat, mampu mendekonstruksi pola pemikiran umat Islam Indonesia dengan mencairnya kelompok aliran. ${ }^{35}$

Kedua, kelompok tradisional dan pembaharu yang mengalami perubahan. ${ }^{36}$ Ketiga, gerakan Islam Fundamentalis yang mempunyai cita-cita untuk mendapatkan kembali The Golden Age of Islam, ${ }^{37}$ yakni gerakan Padri seperti Wahabiyah di Saudi Arabia ${ }^{38}$ dan DI/TII SM Kartosuwiryo pada 7

intellectual freedom, idea of progress dan sikap inclusive. Pemikirannya mendapat reaksi keras ketika Ia menyampaikan pidato keagamaan "Beberapa Renungan tentang Kehidupan Keagamaan di Indonesia" di Taman Ismail Marzuki (TIM) Jakarta pada tanggal 21 Oktober 1992. Fachry Ali dan Bahtiar Effendy, Merambah Jalan Baru Islam: Rekonstruksi Pemikiran Islam Indonesia Masa Orde Baru, (Bandung: Mizan, 1992), hlm.,123 dan Nurcholishh Madjid, Islam Kemodernan dan KeIndonesiaan, (Bandung: Mizan, 1992), hlm.,325 serta Budhy Munawar Rachman, Islam Pluralis : Wacana Kesetaraan Kaum Beriman. (Jakarta: Raja Grafindo Persada, 2004), hlm.,574.

35 M. Rasjidi, Koreksi terhadap Drs. Nurcholishh Madjid tentang Sekularisasi, (Jakarta: Bulan Bintang, 1977), Endang Saefuddin Anshari, Kritik atas Faham dan Gerakan Pembaharuan Nurcholishh Madjid, (Bandung: Bulan Sabit, 1973). hlm., 54 dan Budi Handrianto, 50 Tokoh Islam Liberal Indonesia Pengusung Ide Sekularisme, Pluralisme, dan Liberalisme Agama, (Jakarta: Hujjah Press, 2007), hlm.,58.

${ }^{36}$ Ahmad Ali Riyadi, Dekonstruksi Tradisi Kaum Muda NU Merobek Tradisi, (Yogyakarta: Ar-Ruzz Media, 2007), hlm.,31

37 Kalim Siddiqui, Seruan-seruan Islam: Tanggung Jawab Sosial dan Kewajiban Menegakkan Syari'at, terj. Akhmad Affandi dan Humaidi (Yogyakarta: Pustaka Pelajar, 2002). hlm.,22.

${ }^{38}$ Burhanuddin Daya, Gerakan Pembaharuan Pemikiran Islam: Kasus Sumatera Thawalib,(Yogyakarta: Tiara Wacana, 1995), hlm.,50 
Agustus 1949, serta NII Kahar Muzakar di Sulawesi Selatan, dan Gerakan Daud Beureuh di Aceh. ${ }^{39}$ Kelompok keempat, yaitu kelompok Islam Radikal - yang kemudian dikenal dengan Gerakan Salafi Militan. ${ }^{40}$

Pada tipologi ini, menurut penulis bahwa Soekarno berada pada kelompok pembaharu (modernis) dan Islam kontekstual. Soekarno banyak menggagas tentang pemikiran ke-islaman. Tulisan Soekarno yang populer dalam buku berjudul Di bawah Bendera Revolusi secara rinci, yaitu "Nasionalime Islamisme, Markisme". "kearah persatuan", Tabir adalah lambang perbudakan, Apa sebab Turki Memisah Agama dari Negara, dan Saya Kurang Dynamis, dan Masjarakat Onta dan Masjarakat Kapal Udara, suratsurat Islam dari Ende, Memudahkan pengertian Islam (1940), Masjarakat Onta dan Masjaratakat Kapal, dan Islam Sontolojo (1940). ${ }^{41}$

Dengan demikian, maka penulis memosisikan Soekarno pada kelompok pembaharu dan kontekstual. Hal ini didasarkan pada Sistem berpikir dari teori transformasi Bill Gould tentang

39 Haedar Nashir, Gerakan Islam Syari'at: Reproduksi Salafiyah Ideologis di Indonesia,. Loc. Cit, hlm.,282.

40 Noorhaidi Hasan, Laskar Jihad: Islam, Militansi, dan Pencarian Identitas di Indonesia Pasca Orde Baru, (Jakarta: Pustaka LP3ES dan KITLV, 2008), hlm.,31. ide-ide dasar trans-formatif dan transformatif versi Kuntowijoyo yang memaknai trans-formatif dengan liberalisasi (pem-bebasan dari keterpurukan), serta gerak intelektual dan sosial Karl Stembrink.

2. Pemikiran Transformatif Soekarno Tentang Sekularisasi Politik Islam Sesudah Kemerdekaan.

Pengelompokan keislaman dalam tipologi pemikiran Islam, penulis setuju dengan pendapatnya Munawir Sadzali yang dikutip Haedar Nashir dalam disertasinya berjudul Gerakan Islam Syariat: Reproduksi Salafiah Idiologis di Indonesia, yang diterbitkan oleh Pusat Studi Agama dan Peradaban (PSAP) Muhammadiyah tahun 2007, beliau membagi tiga kelompok muslim tentang pandangan kesatuan antara agama dengan negara. Pendapat tersebut, yakni:

a. Islam bukan hanya menyangkut hubungan manusia dengan tuhan. Melainkan Islam adalah agama sempura dan lengkap yang mengatur segala aspek kehidupan manusia dan bernegara. Di dalamnya mengatur sistem ketatanegaraan atau politik, yakni zaman Nabi Muhammad dan KhulafaaurRasidin, sehingga dalam pemahaman kelompok ini bahwa tidak bisa dipisahkan antara

${ }^{41}$ Untuk lebih jelas bisa baca, Soekarno, $D i$ Bawah Bendera Revolusi, Loc. cit., hlm. 102-207. 
agama dengan negara. Adapun tokohnya ialah Syekh Hasan AlBana, Sayyid Quyyb, Syekh Muhammad Rasyid Ridal, dan Al-Maududi.

b. Islam tidak mengatur hubungan dengan negara. Nabi hanya seorang rasul yang mengajak manusia untuk menjunjung tinggi budi pekerti yang luhur dan tidak mendirikan negara Islam. Pemahaman kelompok ini bahwa negara harus terpisah dari agama. Adapun tokohnya ialah Thaha Husain dan Ali Abd Al-Raziq.

c. Dalam ajaran Islam tidak terdapat sistem ketatanagaraan tetapi terdapat seperangkat tata nilai dan etika kehidupan bernegara. Tokohnya ialah Muhammad Husain Haikal. ${ }^{42}$

Kelompok pertama menurut Haedar disebut aliran tradisional atau integralistik, aliran kedua disebut dengan kelompok sekular atau reformis-sekular sedangkan kelompok ketiga disebut kelompok modernis. ${ }^{43}$ Pengelompokan tersebut disebabkan karena kondisi dunia Islam yang suram yaitu: pertama, kehilangan kreativitas dan menafsirkan karya ulama terdahulu. $^{44}$ Kedua, kehilangan

${ }^{42}$ Ibid., hlm. 109.

43 Harun Nasution, Pembaharuan Dalam Islam: Sejarah Pemikiran dan Gerakan, (Jakarta: Bulan Bintang, 1975), hlm.,13.

${ }^{44}$ Nurcholishh madjid, "Tradisi Syarah dan Hasiyah dalam Fiqh dan Masalah Stagnasi Pemikiran Hukum Islam”, dalam Kontekstualisasi kontrol terhadap akulturasi budaya luar Islam untuk melakukan ritual dan tawasul. ${ }^{45}$ Ketiga, menyibukkan diri membangun kesalehan teologis "sufi". 46 Ketiga, hal tersebut mengidentifikasikan munculnya gerakan Islam Tradisional, ${ }^{47}$ atau Revivalis atau Fundamentalis. ${ }^{48}$

Dari pengelompokkan di atas, penulis memposisikan Soekarno dalam kelompok nasionalis sekular. Hal ini terungkap dalam pernyataan Soekarno yang mengutip pernyataan Kemal Pasha tentang pemisahan agama dan negara, "Jangan marah, kita bukan melempar agama kita, kita cuma menyerahkan agama kembali ke tangan rakyat kembali, lepas dari urusan negara supaya agama dapat menjadi subur". Dengan mengutip pernyataan ini, Soekarno ingin membenarkan pendapatnya

Doktrin Islam dalam Sejarah, Budhy MunawarRachman (ed). (Paramadina: Jakarta, 1994), hlm.,311.

${ }^{45}$ Tentang ziarah ke makam para wali di Dunia Islam seperti Mesir, Sudan, Maroko, Tunisia, Turki, dll, Lihat Henri Chambert Loir dan Claude Guillot (ed). Ziarah dan Wali di Dunia Islam, ter. Jean Couteau et.al (Jakarta: Serambi, 2007). hlm., 211.

46 Tarekat pada periode ini adalah tarekat Qadiriyah, Sadziliyah, Satariyah, dll. Lihat Sri Mulyati, Mengenal dan Memahami Tarekat-tarekat Muktabarah di Indonesia, (Jakarta: Kencana, 2006). hlm., 32.

${ }^{47}$ Nurcholishh madjid (ed)., Ibnu Taimiyah, "Tangga Pencapaian”, dalam Khazanah Intelektual Islam, (Jakarta: Bulan Bintang, 1985), hlm.,247..

48 Anthony Black, Pemikiran Politik Islam dari Masa Nabi Hingga Masa Kini., ter. Abdullah Ali et al (Jakarta: Serambi, 2006), hlm.,496. Philip K. Hitti, History of the Arabs, terj. Cecep Lukman 
yang meninggalkan agama dalam kehidupan bernegara di Indonesia. Ia ingin menyatakan bahwa dalam negara Indonesia yang sekular, Islam akan tumbuh lebih baik, sesuatu yang sebenarnya tak pernah dibuktikan oleh Kemal Pasha sendiri di Turki. ${ }^{49}$

Sekularisme memiliki arti fashluddin ani haya yang artinya adalah memisahkan peran agama dari kehidupan. ${ }^{50}$ Menurut Cox, sekularisasi adalah akibat logis dari dampak kepercayaan Bible terhadap sejarah. ${ }^{51}$ Sekularisasi adalah pembebasan manusia dari arusan agama. Menurut Syed naquib Al Attas, Sekularisasi adalah pandangan dunia diperbarui sesuai dengan perubahan evolusioner sejarah. $^{52}$ Tiga komponen integral dalam secularisasi, yaitu: pertama,

Disentchantmen of nature atau pembebasan alam dari nada-nada keagamaan, memisahkannya dari Tuhan. ${ }^{53}$ Kedua, de-acralization of politics, yaitu penghapusan legitimasi sakral kekuasaan politik. Ketiga, deconsecration of values,

Yasin, et.al (Jakarta: Serambi Ilmu Semesta, 2005), hlm.,954.

${ }^{49}$ Ibid., hlm. 133.

50 Taqiyuddin An-Nabhani. Peraturan Hidup dalam Islam, ( Bogor : Pustaka Tariqul Izzah, 2001), hlm. 413.

51 Adian Husaini. Wajah Peradaban Barat : Dari Hegemoni Kristen Ke Dominasi SekularLiberal, (Jakarta : GIP ; 2005), hlm. 257

${ }^{52}$ S.N. Al-Attas. Op. cit. hlm. 23

53 Budhy Munawar-Rachman, Reorientasi Pembaruan Islam: Sekularisme, Liberalisme, dan Pluralisme Paradigma Baru Islam Indonesia. 2010. Loc. cit., hlm. 166 yaitu pemberian nilai kepada semua karya budaya. ${ }^{54}$ Esensi dari sekularisasi politik sesungguhnya adalah modernisasi politik yang memiliki ciri; (a) pemisahan politik dari ideologi agama; (b) ekspansi politik; (c) transvaluasi kultur politik; (d) dominasi politik atas keyakinan agama. ${ }^{55}$ Menurut Thaha Husein, politik dan agama adalah dua hal yang terpisah. ${ }^{56}$

Dalam istilah politik, sekularisme adalah suatu gerakan terhadap pengasingan agama dan kerajaan. ${ }^{57}$ Sekularisme sering dikaitkan dengan pemisahan gereja dan negara. ${ }^{58}$ Ahli sekular lebih suka ahli politik membuat keputusan untuk sekular dari pada alasan agama. ${ }^{59}$ In this respect, policy decisions pertaining to topics like abortion, contraception. ${ }^{60}$

${ }^{54}$ S. N. A 1 - A t t a s. Op. cit. hlm. 21

55 Donald Eugene Smith, Religion and Political Development: an Analytic Study. (Boston: Little, Brown and Company, 1970), hlm. 85-86.

${ }^{56}$ Muhammad Al-Bahiy, Al-Fikr al-Islam alHadits wa Siratuh bi al-Isti'mar al-Garbiyy, diterjemahkan oleh Su'adi Sa'ad dengan judul Pemikiran Islam Modern. (Jakarta : Pustaka Panjimas, 1986). hlm. 110.

57 Feldman, Noah (2005). Divided by God. Farrar, Straus and Giroux, pg. 14 ("[Legal secularists] claim that separating religion from the public, governmental sphere is necessary to ensure full inclusion of all citizens.")

58 Ira M. Lapidus (October 1975). "The Separation of State and Religion in the Development of Early Islamic Society", International Journal of Middle East Studies 6 (4), hlm. 363-385.

${ }^{59}$ Feldman, Noah Divided by God. (Farrar ; Straus and Giroux ; (2005), hlm. 6-8.

60 Washington Post, November 15, 2006 "Think Tank Will Promote Thinking" dan "Declaration in Defense of Science and Secularism" 
Sekularisasi politik Islam seperti dikatakan Azzam Tamimi merupakan penyusup ke dalam pemikiran politik Islam. $^{61}$ Seperti dicatat Syamsuddin Arif proses sekularisasi dalam dunia Islam dimulai sejak dihapusnya sistem khilafah Turki Utsmani. ${ }^{62}$ Nurcholish Madjid membuat pemikiran tanah air dengan gagasan sekularisasi yang dilanjutkan oleh Komaruddin Hidayat, ${ }^{63}$ yang menyatakan bahwa sekularisme muncul di Turki sebagai kritik atau perlawanan balik dari gerakan republikanisme terhadap kekuasaan Uthmani. ${ }^{64}$ Abdur Rahman Wahid menyebutkan pemisahan wewenang fungsional antara agama dan negara tidak berarti bahwa negara kita adalah negara yang murni sekular. ${ }^{65}$ Sekularisasi dalam arti pemisahan wewenang itu harus dibedakan secara tajam dari sekularisme ataupun situasi sekular, karena dalam sekularisme tidak ada hubungan sama sekali antara

61 Azzam Tamimi, Hamas: A History from Within (London; Olive Branch Press ; 2007). hlm. 372.

${ }^{62}$ Syamsuddin Arif, Menyerang Orientalis di Sarangnya, Majalah Hidayatullah terbit tanggal 28 Mei 2008. hlm. 109.

${ }^{63}$ Hidayat., Komaruddin., dan M. Wahyudi Nafis, Agama Masa Depan, Perspektif Filsafat Perennial, (Jakarta Terbitan Ulang Paramadina ; 2003), hlm. 155.

${ }^{64}$ Ibid., hlm. 157

65 Luthfi. A. Assyaukanie , "Tipologi dan Wacana Pemikiran Arab Kontemporer", dalam http:media.isnet.org, hlm. 88. agama dan negara. ${ }^{66}$ Muhammad al-Bahy menyatakan bahwa Islam dan sekularisme me-rupakan dua hal yang antagonistik, karena posisi Islam kebalikan dari sekularisme.

Selanjutnya, Gagasan Raziq, yakni "Nabi Muhammad itu adalah rasul dan tidak membentuk negara." Lebih lanjut, Raziq mengatakan kalau Islam adalah, "Risâlah lâ hukm, wa dîn lâ dawlah." (Islam adalah agama, bukan Negara). Menurut Abdullah Ahmad An-Na'im negara secara kelembagaan haruslah dipisahkan dari Islam. ${ }^{67}$

Arkoun menganggap bahwa Islam agama sekular. Gagasan sekular terdapat di dalam alQur'an dan pengalaman Madinah. ${ }^{68}$ Dalam pemikiran Arkoun, gagasan sekular-isasi adalah sikap spirit dan merupakan kompetisi untuk meng-uasai kebenaran atau mencapai kebenaran. ${ }^{69}$ John L Esposito berpendapat bahwa sekularisasi sebagai bentuk kebangkitan Islam (revivalisme Islam). ${ }^{70}$ Tetapi al-

66 Toprak, Binnaz., Islam and Political Development in Turkey, (Leiden : E.J. Brill,: 1981), hlm. 322.

67 Ibid. hlm. 225

68 Suadi Putro, Mohammed Arkoun Tentang Islam dan Modernitas (Jakarta; Paramadina, 1998, hlm. 79.

69 Muhammad Arkoun, al-'Almanah wa al$D \hat{E} n$ (al-IslÉm, al-Mast̂hiyyah-al-Gharb), Pen. HÉshim ØÉliÍ (London: DÉr al-SÉqÊ, 1990), hlm. 9-11, selanjutnya diringkas Al-' 'almanah.

${ }^{70}$ John L. Esposito, Islam: The Straight Path, (New York ; Oxford: Oxford Univbersity Press ; 1988)., hlm, 88. Moaddel, Mansoor, The Studi Culture and 
Maududi berbeda. Al-Maududi mengakui adanya Negara Islam sebagaimana pernyataanpernyataan Kitab Suci Al-Qur'an dan praktik Rasulullah serta para Khulafa al-Rasyidin. ${ }^{71}$ Hasan AlBana menyatakan bahwa Islam tidak mengenal pemisahan antara agama dan politik, Islam merupakan agama menyeluruh dalam aspek kehidupan. Menurut Z.A. Ahmad, bahwa Daulah Islamiyah atau Negara Islam, bukan saja saja diajarkan oleh Nabi, tetapi juga sudah pernah dibangun pada masa hidupnya. ${ }^{72}$ Amin Sa'id menunjukkan syarat dan rukun yang terpenuhi seputar Negara Islam, yaitu: peraturan dan undangundang, ada pemerintahan; ada tentara; ada sumber keuangan; ada rakyat; dan ada tanah air. $^{73}$ Leonard Bender berupaya melacak keterkaitan liberalisme Islam dengan liberalisme politik di Timur Tengah. Binder menyimpulkan bahwa tanpa adanya liberalisme Islam, maka liberal-

Politics : An Overview and Assessment. Annual Review of Sosiology 28 (2002) 359-386 Moaddel, Mansoor, Islamic Modernism, Nationalism, and Fundamentalism : Episode and Discourse, (Chicago, University of Chicago Press. 2005), hlm. 222

71 Abul A'la Al-Maududi, Sistem Politik Islam, terj. Asep Hikmat (Bandung: Mizan, 1995), hlm. 158.

72 Z.A. Ahmad, Membentuk Negara Islam, (Jakarta: Penerbit Widjaya, 1956), hlm. 18.

73 Charles Kurzman, Wacana Islam Liberal: Pemikiran Islam Kontemporer tentang Isu-isu Global. (Jakarta : Paramadina :, 2001), hlm. 112. Lihat juga Antony Black. Pemikiran Politik Islam: Dari Masa Nabi Hingga Masa Kini, Loc. cit., hlm. 539. isme politik tidak akan terjadi di Timur Tengah. Untuk medukung tesis tersebut, Binder menyatakan bahwa Islam merupakan bagian dari liberalisme (a subset of liberalism $)^{74}$

Pada tipologi ini, menurut penulis bahwa Soekarno berada pada kelompok nasionalis sekular. Soekarno sangat serius mewacanakan gagasan Indonesia yang sekular lewat diskusi-diskusi dan tulisan-tulisannya. Tercatat beberapa tulisan Soekarno yang ingin memisahkan Islam dari ranah kehidupan bernegara seperti: Apa Sebab Turki Me-misahkan Agama dari Negara, Masyarakat Onta dan Masyarakat Kapal Udara, Islam Sontoloyo, dan lain sebagainya. Gagasan sekularisme Indonesia ini benar-benar terwujud setelah Indonesia diproklamasikan dan Soekarno dipilih menjadi presiden pertama RI. Sebelumnya bahkan upaya ini telah menjadi bahan perdebatan yang hangat di sidang BPUPKI dan PPKI. ${ }^{75}$

3. Perlakuan Sukarno terhadap Sekularisme.

Sebagaimana nanti diperlihatkan, analisa yang disajikan dalam naskah ini berusaha melacak bagaimana Sukarno mengkaitkan

74 Leonard Binder, Islamic Liberalism: A Critique of Develompment Ideologies (Chicago and London: The University of Chicago Press, 1988). hlm. 19.

75 Budhy Munawar-Rachman, Reorientasi Pembaruan Islam: Sekularisme, Liberalisme, dan Pluralisme Paradigma Baru Islam Indonesia. 2010. Loc. cit., hlm. 176. 
dua geraknya ditarik dari dua gerak di atas, yakni gerak pemikiran intelektual Soekarno dan gerak pemikiran sosial politik tersebut di atas. Pemikiran Soekarno kita labeli sebagai pemikiran transformatif manakala gagasannya berkembang dari level pemikiran modernis menjadi politisi sekular dan bahkan Soekarno sebagai seorang sekularis. Sebaliknya pemikirannya tidak bisa kita labeli transformatif manakala dalam pemikiran Soekarno tidak terjadi perkembangan dari level pemikiran modernis kepada lever sekular dan bahkan melakukan sekularisasi politik Islam di Indonesia. Sekali lagi, transformatif pemikiran ditandai oleh perkembangan dari level pemikiran modernis kepada lever sekular yang melakukan sekularisasi. Dalam gerak pemikiran sosial politik Soekarno, penulis menarik kesimpulan bahwa dalam pemikiran Soekarno telah terjadi transformasi, yang penulis sebut dengan Pemikiran Transformatif Soekarno dalam politik Islam.

Ketiga gagasan mengenai posisi pemikrian Soekarno di atas, dapat dijelaskan sebagai proses yang berlanjut, berkembang, dan kontinyu dengan menggunakan teori rasionalisasi ala Weber. Menurut Weber, proses rasionalisasi merupakan ciri perubahan dari masyarakat tradisional men- jadi masyarakat modern. Kekuatan rasionalisasi mampu mengubah dari diferensiasi sosial sederhana pada masyarakat tra-disional menjadi proses diferensiasi sosial komplek pada masyarakat modern. Proses perubahan ini disebut sebagai atau merupakan inti dari konsep civilisasi atau budaya. dalam konteks ini transformasi yang terjadi pada soekarno dapat dimaknai sebagai proses rasionalisasi dan proses berbudaya (sivilisasi). Artinya, Soekarno menjadi aktor rasionalisasi dan modernis sejak pada tahap pemikir sampai dengan tahap pengambil kebijkan. Pada dua tahap per-kembangan tersebut, pada hakikatnya merupakan satu rangkaian proses, yaitu proses rasionalisasi dan proses berbudaya.

\section{DAFTAR PUSTAKA}

Adams, Cindy. 1984. Bung Karno Penyambung Lidah Rakyat Indonesia. Terj. Abdul Bar Salim. Jakarta: Gunung Agung.

$$
\begin{aligned}
& \text { Autobiography as Told to Cindy } \\
& \text { Adams. New York: The Bobs } \\
& \text { Merry l Company Inc. }
\end{aligned}
$$

Ahmad, Z.A. 1956. Membentuk Negara Islam. Jakarta: Penerbit Widjaya.

Ali, Stiakh Amir. 1979. The Spirit of Islam, New Delhi: IdarahAdabiyah-i Delhi.

A. Muhaimin. Yahya. 1982. Perkembangan Militer dalam 
Politik Indonesia 1945-1966.

Yogyakarta: Gadjah Mada University Press.

Anshari, Endang Saefuddin. 1975. Kritik atas Faham dan Gerakan Pembaharuan Nurcholish Madjid. Bandung: Bulan Sabit.

1986. Piagam Jakarta 22 Juni 1945: dan Sejarah Konsesnsus Nasional Antara Nasionalis Islam dan Nasionalis Sekuler Tentang Dasar Negara RI 1945-1959. Jakarta: CV Rajawali Press.

2004. Wawasan Islam PokokPokok Pikiran Tentang Paradigma dan Sistem Islam. Jakarta: GIP.

Anshary, Isa. 1958. Manifest Perjuangan Persatuan Islam. T.K: TP.

Arabi, Ibn. t.t. Al-Futuhat al-Makkiyah, Bairut: Dar Ihya' al-Turats alArabi.

Arifin, Syamsul. 2005. Ideologi dan Praksis Gerakan Sosial Kaum Fundamentalis. Malang: UMM Press.

Arkoun, Muhammad. 1990. al'Almanah wa al-DÊn (al-IslÉm, al-MasÊhiyyah-al-Gharb). Pen. HÉshim ØÉlií London: DÉr alSÉqÊ. 1990.

Binder, Leonard. 1988. Islamic Liberalism: A Critique of Develompment Ideologies. Chicago and London: The University of Chicago Press.
Binnaz, Toprak. 1981. Islam and Political Development in Turkey. Leiden: E.J. Brill.

Blavatsky, Helena Petrovna. 1972. Kunci Pembuka Ilmu Theosofi. Terj. R.S. Suyatno. Jakarta: Pustaka Theosofi Perwathin.

Dahm, Benhard. 1987. Soekarno dan Perjuangan Kemerdekaan. Terj. Hasan Basri. Jakarta: LP3ES.

Djaya, Tamar. 1983. Soekrno Hatta Ada Persamaan dan Perbedaannya. Jakarta: Sastra Hudaya.

Esposito, John L. 1988. Islam: The Straight Path. New York: Oxford: Oxford Univbersity Press.

Falah, Maslahul. 2003. Islam Ala Soekarno Jejak Langkah Pemikiran Islam Liberal Indonesia. Yogyakarta: Kreasi Wacana.

Feith, Herbert. 1962. The Decline of Constitutional Democracy in Indonesia.

Umum 1955 Di Indonesia. Jakarta: Kepustakaan Populer Gramedia.

Feith, Herber., t dan Lane. 1988. Pemikiran Politik Indonesia 19451965. Jakarta: LP3ES.

Hamid Algadri. 1984. C. Snouck Hurgronye, Politik Belanda terhadap Islam, dan Keturunan Arab. Jakarta: Sinar Harapan.

Hakim, Khalifa Abdul. 1976. Islam and Communism. Lahore: Institute of Islamic Culture. 
Ingleson, John. 1983. Jalan ke Pengasingan, Pergerakan Nasional Indonesia tahun 19271934. Terj. Zamakhsari Dhofier. Jakarta: LP3ES.

Jurgensmayer, Mark. 1998. Menentang Negara Sekular. Bandung: Mizan.

Karim, Rusli. 1983. Perjalanan Partai Politik Indonesia: Sebuah Potret Pasang Surut. Jakarta: PT. Rajawali.

Kartodirdjo, Sartono., Marwati D.P., \& Nugroho Notosusanto. 1975. Sejarah Nasional Indonesia VI. Jakarta: Departemen Pendidikan dan Kebudayaan.

Kasenda, Peter. 2010. Soekarno Muda: Biografi Pemikiran 1926-1933. Jakarta: Komunitas Bambu.

Kurzman, Charles. 2001. Wacana Islam Liberal: Pemikiran Islam Kontemporer tentang Isu-isu Global. Jakarta: Paramadina.

Legge, J. D., Soekarno, Sebuah Geografi Politik, Terj. Tim PSH. Jakarta: Sinar harapan: 1985.

Madjid, Nurcholish. 1992. Islam Kemodernan dan KeIndonesiaan. Bandung: Mizan.

Mansoor, Moaddel. 2005. Islamic Modernism, Nationalism, and Fundamentalism: Episode and Discourse. Chicago: University of Chicago Press.

Moedjanto, G. 1988. Indonesia Abad Ke 20 Jilid II: Dari Perang Kemerdekaan Sampai Pelita III. Yogyakarta: Kanisius.
Mortimer, Edwar. 1984. Islam dan Kekuasaan. Terjemahan Anna Hadi dan Rahmani Astuti. Bandung: Mizan.

Noer, Deliar. 1987. Partai Islam di Pentas Nasional 1945-1965. Jakarta: PT. Pustaka Utama Grafiti, Cetakan Pertama.

Notosoetardjo, A. 1963. Peranan agama Islam dalam Revolusi Indonesia, Djakarta: Lembaga Penggali dan Penghimpun Sejarah Revolusi Indonesia.

Ongkhokam. 1978. "Soekarno: Mitos dan Realitas", dalam Taufiq Abdullah, et. al., (ed.). Manusia datam Kemelut Sejarah. Jakarta: LP3ES.

Panitia Peringatan 100 Tahun Bung Karno. 2001. Bung Karno dan Wacana Islam: Kenangan 100 Tahun Bung Karno. Jakarta: PT Grasindo.

Panitia Lima. 1977. Uraian Pancasila. Jakarta: Mutiara.

Peursen, C.A. Van. 1976. Strategi Kebudayaan. Terjemahan Dick Hartono. Jakarta: BPK Gunung Mulia \& Kanisius.

Putro, Suadi. 1998. Mohammed Arkoun Tentang Islam dan Modernitas. Jakarta: Paramadina.

Rahardjo, Dawam. Published June 1. 2009. Agama Leave a Comment Tags: Ahmadiyah, Ahmadiyyah, Indonesia, Islam, Islam Liberal, Khalifah, Muhamadiyah, NU, RI, Soekarno. 
http://denagis.wordpress.com/2009

/0/ 01/Soekarno-pelopor-

pemikiran-islam-liberal.

Ramage, Douglas E. 1995. Democracy, Islam, and The Ideology of Tolerance. Terjemahan Hartono Hadikusumo. Yogyakarta: Matahari.

Raziq, Ali Abdur. 1925. Al-Islam wa ushul Al-Hukm, Bahs fi Al-Khilafat wa Al-Hukm Al-Islamiyat. Kairo: Musahamat Mishriyyat. t.p.

Runes. Dagobert D. (ed.). 1971. Dictionary of Philosophy, Totowa: Littlefield, Adams \& Cc.

Sagimun. 1986. Perlawanan dan Pengasingan Pejuang Nasional. Jakarta: Idayu.

Salam, Solichin. 1984. Bung Karno dan Kehidupan Berpikir dalam Islam. Jakarta: Wijaya.

1933. Soekarno Sebagai Manusia. Solo: Boeckhandel Ravena.

Schumann, Olaf. 2011. Agama-agama: Kekerasan dan Perdamaian. Jakarta: BPK Gunung Mulia.

Setyohadi, Tuk. 2002. Sejarah Perjalanan Bangsa Indonesia dari Masa ke Masa. Jakarta: CV. Rajawali Cooporation.

Shodiq, Abdullah. 1994. Sekularisme Soekarno dan Mustafa Kemal. Pasuruan: PT Garoeda Buana Indah

Soekarno. 1963. Di Bawah Bendera Revolusi, jilid pertama cet. Kedua.
Jakarta: Panitia di Bawah Bendera Revolusi.

1985. Amanat Soekarno I, 1945-1950. Jakarta: PT. Inti Idayu Press, Yayasan Pendidikan Soekarno.

Mewajibkan Syariat Islam bagi Pemeluk-pemeluknya. Departemen Agama.

Simatupang, T.B. 1982. Antara Citra dan Fakta, dalam Aristides Katoppo (ed.), 80 Tahun Bung Karno. Jakarta: Sinar Harapan: 1982.

Simorangkir, O.P. 2002. Renungan Bung Karno Bapak Marhaen Indonesia. T.K: Tim Studi Pembudayaan Pancasila Universitas Krisnadwipayana. 